\title{
Effect of foliar iron sulfate on the fruit growth and quality of pineapple (Ananas comosus cv. Yellow Mauritius) planted in lateritic soil in Leizhou Peninsula
}

\author{
ShengHui Liu ${ }^{1,2}$, ZhuYing $\mathrm{Zhu}^{1,2}$, YuMei Zhang ${ }^{1,2}$, QingSong $\mathrm{Wu}^{1,2}$, and XiuMei Zhang ${ }^{1,2 *}$ \\ ${ }^{1}$ Key Laboratory of Tropical Fruit Biology, Ministry of Agriculture, China. \\ ${ }^{2}$ South Subtropical Crops Research Institute, Chinese Academy of Tropical Agricultural Science (CATAS), Zhanjiang City, 524091, \\ Guangdong Province, China.
}

\begin{abstract}
Leizhou Peninsula in South China is facing a serious water shortage problem because of the special regional and geological conditions. As a kind of low water requirement crop, pineapple has been popular in lateritic soil. However, the physical characteristics of Lateritic soil such as too cohesive, impervious, low content of organic matter, and seasonal arid often bring some problem to pineapple cultivation. Seasonal iron deficiency can be easily observed from April to July. The effect of foliar spray of iron sulfate (with concentration of $0,0.5 \%, 0.75 \%, 1 \%$ ) on the fruit growth and quality of pineapple cv. Yellow Mauritius were studied in this research. Results showed that there were no significant difference $(p>0.05)$ on the fruit weight, longitudinal diameter, transverse diameter among all the treatment. $0.75 \%$ treatment increased the fruit weight to $6.08 \%$ and decreased crown weight significantly. Both $0.75 \%$ and $1 \%$ iron sulfate treatment not only enhanced vitamin $\mathrm{C}$ extremely significantly, but also improved the aroma quality significantly with the increase of total esters, especially in the content of hexanoic acid methyl ester, 3-(methyl tio) propanoic acid methyl ester and 2-methyl- butanoic acid methyl ester. The content of these 3 esters above were all extremely significantly higher than control, which means much stronger pleasant aroma. Hence, $0.75 \%$ was the optimal concentration of foliar spray with iron sulfate in pineapple cv. Yellow Mauritius.
\end{abstract}

\section{Introduction}

Leizhou Peninsula in South China is facing a serious water shortage problem because of the special regional geomorphological and geological conditions, and surface water has been lacking ${ }^{[1]}$. Lateritic soil is a problematic soil in leizhou Peninsula. This soil is distributed generously along the coast of Leizhou Peninsular in Guangdong Province, China, from Zhanjiang City, Leizhou City to Xuwen County. The physical characteristics of Lateritic soil are too cohesive, impervious, low content of organic matter, and seasonal arid often bring some problems to plant cultivation.

Pineapple is one of the main crops in Leizhou Peninsula ${ }^{[2]}$ due to its lower water requirement than the vast majority of cultivated plants ${ }^{[3]}$. It occupied more than 50 percent pineapple planting area in China. As a crassulacean acid metabolism (CAM) plant, pineapple has a series of morphological and physical characteristics typical of xerophile plants. The thick cuticle, the water storage tissue, the disposition of the stomata, and the trichomes all contribute to the remarkable water economy of pineapple. The leaf cup can collect rain water or dew, and the capacity to store water in the hypoderm of the leaves makes plant has strong tolerance to arid climate.
Furthermore, pineapple adapts well to acidic soils with optimal $\mathrm{pH} 4.5$ to $5.5^{[4]}$ which commonly occurred at lateritic land.

However, seasonable Iron deficiency of pineapple is very common in Leizhou Peninsula ${ }^{[4]}$. The leaf color became shallow green, yellow and pale, and thin. Severe iron deficiency even can cause death of plants. Those plants with iron deficiency at the stage of reproductive growth priod have fruits that are small, hard and reddish in color and with cracking between the fruitlets ${ }^{[5]}$. Iron is an immobile nutrient so iron deficiency symptoms always appear first on young leaves and foliar spray iron element is a very effective way to make up the common demands. In this article, iron sulfate at different concentration of were applied to the pineapple plant to determine the effects of iron fertilizer on the fruit quality of pineapple cv. Yellow Mauritius planted in Lateritic soil.

\section{Materials and Methods}

\subsection{Materials and treatments}

Planting materials of pineapple "Yellow Mauritius" were obtained from South subtropical crops research institute. Suckers were grown in Mazhang District, Zhangjiang City, Guangdong Province. The plants were arranged according

*Corresponding author's e-mail: asiazhang1975@163.com 
to complete randomized design (CRD) with three replications. The basic soil nutrient data is bellows: $\mathrm{pH} 4.4$, content of organic matter $2.3 \mathrm{~g} / \mathrm{kg}$, total nitrogen $0.9 \mathrm{~g} / \mathrm{kg}$, available phosphorus $5.0 \mathrm{mg} / \mathrm{kg}$, available potassium $130.4 \mathrm{mg} / \mathrm{kg}$, exchangeable calcium $10.0 \mathrm{cmol} / \mathrm{kg}$, exchangeable magnesium $2.6 \mathrm{cmol} / \mathrm{kg}$.

Fertilizer was applied twice followed to ordinary cultivation: urea $(45 \% \mathrm{~N})$ at $375 \mathrm{~kg} \cdot$ ha- 1 , triple NPK (15:15:15) compound fertilizer at $300 \mathrm{~kg} \cdot \mathrm{ha}^{-1}$, and once potash magnesium sulfate fertilizer at $500 \mathrm{~kg} \cdot \mathrm{ha}^{-1}$. Iron sulfate solution was sprayed on foliar at the concentration of $0,0.5,0.75,1.0 \% 2$ weeks after flower termination. Each plant was sprayed with iron solution on the surface of the leaves and the fruit for $20 \mathrm{~mL}$.

\subsection{Measurement of fruit growth, external and internal fruit quality}

The fruit external quality (Table 1) and internal quality (Table 2,3) were measured accordingly to the standard method. The total titratable acidity was assessed as outlined by AOAC ${ }^{[6]}$. Vitamin $\mathrm{C}$ was determined by the Dichloroindophenol method AOAC ${ }^{[7]}$. Soluble solids were determined using an Abbe refractometer ${ }^{[8]}$. Total carbohydrates were estimated by the Anthrone Method ${ }^{[9]}$. Aroma compounds were measured by SPME-GC-MS method ${ }^{[10]}$.

\subsection{Data analysis}

DPS 9.5 (Statistical software, Zhejiang University, China) was used to analyze the data, Duncan's Multiple Range Test (DMRT) was used to assess differences among different treatments at $95 \%$ confidence level.

\section{Results and Discussion}

The cv. Yellow Mauritius fruit growth and external quality including fruit weight, crown weight, longitudinal diameter, transverse diameter and fruitlet number were measured at mature stage (in table 1). Results showed that there were no significant difference $(p>0.05)$ about all the index except crown weight among all the treatments. The $0.75 \%$ treatment demonstrated the highest fruit weight and lowest crown weight compared to others, and the crown weight was much lighter than control. Although the fruitlet numbers was the fewest among all the treatment, the fruit weight were still heavier than any other treatment with longer and more beautiful fruit shape. It was reported that iron didn't play any important role in enhancing the pineapple yielding, but when iron was deficient, its addition my increase fruit yield of quality, or both ${ }^{[4-5]}$. In this article, $0.75 \%$ iron sulfate can also increase $6.08 \%$ yield than control, which was much lower than the concentration reported in Dr. Chen's report ${ }^{[4]}$. In addition, it also decrease crown weight significantly,

As far as internal quality is concerned, sugars and acids are the main quality index in fruit quality, which endows pineapple special flavor. Results showed that $1 \%$ treatment decreased both the Brix value and total soluble sugars but increased Vitamin $\mathrm{C}$ extremely significantly. With the increase of the iron sulfate concentration, total soluble sugars in fruits decreased, and total titrable acid and Vitamin C increased. 0.5\% iron treatment didn't make any significant difference compared with control. Both $0.75 \%$ and $1 \%$ treatment enhanced Vitamin C extremely significant. Obviously with the decrease of the Brix value and total soluble sugars, organic acid and vitamin c enhanced (in table 2).

Table 1. Effect of iron sulfate on pineapple fruit growth and external quality

\begin{tabular}{lllllll}
\hline Treatment & $\begin{array}{l}\text { Iron sulfrate } \\
\text { concentration }( \\
\%)\end{array}$ & $\begin{array}{l}\text { Fruit weight } \\
(\mathrm{g})\end{array}$ & $\begin{array}{l}\text { Crown weight } \\
(\mathrm{g})\end{array}$ & Longitudinal & Transverse & Fruitlet \\
diameter $(\mathrm{cm})$ & diameter $(\mathrm{cm})$ & number
\end{tabular}

\begin{tabular}{lllllll}
\hline CK & 0 & $1183.56 \mathrm{aA}$ & $213.70 \mathrm{aA}$ & $12.85 \mathrm{aA}$ & $10.21 \mathrm{aA}$ & $85.40 \mathrm{aA}$ \\
1 & 0.5 & $1211.04 \mathrm{aA}$ & $195.14 \mathrm{abA}$ & $13.81 \mathrm{aA}$ & $10.19 \mathrm{aA}$ & $88.00 \mathrm{aA}$ \\
2 & 0.75 & $1255.78 \mathrm{aA}$ & $165.96 \mathrm{bA}$ & $13.85 \mathrm{aA}$ & $10.16 \mathrm{aA}$ & $81.60 \mathrm{aA}$ \\
3 & 1.0 & $1201.36 \mathrm{aA}$ & $201.32 \mathrm{abA}$ & $13.67 \mathrm{aA}$ & $10.33 \mathrm{aA}$ & $84.00 \mathrm{aA}$ \\
\hline
\end{tabular}

a Different lowercase/capital letters in the same column indicate significance of difference at $\mathrm{P}<0.05 / \mathrm{P}<0.01$ levels. The same below.

Strong and pleasing aroma released from mature pineapple fruit has been an important factor to attract most of consumers. To date, more than 280 volatile compounds have been identified among the aroma volatiles of pineapple. Among of these, the most abundant not only kinds but also contents were esters. 13 characteristic aroma compounds and odor activity values of pineapples were studied according to Wei ${ }^{[10]}$. In this article 9 characteristic esters were analyzed and compared among all the treatment (in table 3 ). The total esters in pineapple fruits treated by the iron sulfate increased significantly compared with control. With the increase of iron sulfate, the content of total esters increased especially hexanoic acid methyl ester. Treatment $0.75 \%$ contained the most abundant hexanoic acid methyl ester, 3-(Methyltio) propanoic acid methyl ester, also named pineapple methyl ester, and 2-methyl butanoic acid methyl ester, extremely significantly higher than control, which means much stronger pleasant aroma. It can be observed that there were no significant difference about aroma compounds at iron level from treatment 0 to $0.50 \%$ except hexanoic acid ethyl ester and octanoic acid methyl ester, so did which from treatment $0.75 \%$ to $1.00 \%$. 
Table 2. Effect of iron sulfate on internal fruit quality of pineapple

\begin{tabular}{cccccc}
\hline Treatment & $\begin{array}{c}\text { Iron sulfate } \\
\text { concentration } \\
\%)\end{array}$ & $\begin{array}{c}\text { Brix value } \\
(\%)\end{array}$ & $\begin{array}{c}\text { Total soluble } \\
\text { sugars } \\
\mathrm{mg} / \mathrm{g}\end{array}$ & $\begin{array}{c}\text { Total titrable } \\
\text { acids(\%) }\end{array}$ & $\begin{array}{c}\text { Vitamin C } \\
\mathrm{mg}^{-100 \mathrm{~g}^{-1} \mathrm{FW}}\end{array}$ \\
\hline $\mathrm{CK}$ & 0 & $14.84 \mathrm{a} \mathrm{A}$ & $10.29 \mathrm{aA}$ & $0.29 \mathrm{aA}$ & $5.60 \mathrm{bB}$ \\
1 & 0.50 & $14.92 \mathrm{aA}$ & $10.30 \mathrm{aA}$ & $0.29 \mathrm{aA}$ & $6.99 \mathrm{aAB}$ \\
2 & 0.75 & $14.42 \mathrm{aA}$ & $10.02 \mathrm{aA}$ & $0.34 \mathrm{aA}$ & $7.57 \mathrm{aA}$ \\
3 & 1.00 & $13.38 \mathrm{bB}$ & $8.82 \mathrm{bB}$ & $0.38 \mathrm{aA}$ & $7.82 \mathrm{aA}$ \\
\hline
\end{tabular}

Table3. Effect of iron sulfate on main aromatic compounds in pineapple fruit

\begin{tabular}{|c|c|c|c|c|c|}
\hline \multirow[b]{2}{*}{ peak } & \multirow[b]{2}{*}{ compounds } & \multicolumn{4}{|c|}{ Relative percentage content $(\%)$} \\
\hline & & 0 & 0.50 & 0.75 & 1.00 \\
\hline 1 & Butanoic acid methyl ester & $1.02 \mathrm{aA}$ & $0.76 \mathrm{Aa}$ & $3.07 \mathrm{aA}$ & $3.86 \mathrm{aA}$ \\
\hline 2 & $\begin{array}{l}\text { 2-methyl butanoic acid methyl } \\
\text { ester } \\
\text { 2-methyl butanoic acid ethyl }\end{array}$ & $5.70 \mathrm{bB}$ & $6.94 \mathrm{bB}$ & $14.29 \mathrm{aA}$ & $14.38 \mathrm{aA}$ \\
\hline 3 & ester & $1.04 \mathrm{bAB}$ & $2.17 \mathrm{aA}$ & $1.53 \mathrm{aA}$ & $1.30 \mathrm{abA}$ \\
\hline 4 & Hexanoic acid methyl ester & $28.89 \mathrm{bB}$ & $30.34 \mathrm{bB}$ & $46.23 \mathrm{aA}$ & $45.75 \mathrm{aA}$ \\
\hline 5 & $\begin{array}{l}\text { Hexanoic acid ethyl ester } \\
\text { 3-(Methylthio)propanoic acid }\end{array}$ & $2.0 \mathrm{cC}$ & $9.58 \mathrm{aA}$ & $5.99 \mathrm{bB}$ & $1.46 \mathrm{cC}$ \\
\hline 6 & $\begin{array}{l}\text { methyl ester } \\
\text { 3,7-dimethyl-1,3,6-Octatriene, }\end{array}$ & $4.90 \mathrm{bB}$ & $4.61 \mathrm{bB}$ & $7.18 \mathrm{aA}$ & $6.22 \mathrm{abA}$ \\
\hline 7 & $\begin{array}{l}\text { (Z)- } \\
\text { 4-Octenoic acid methyl ester, }\end{array}$ & $4.09 \mathrm{aA}$ & $5.76 \mathrm{aA}$ & $1.03 \mathrm{bB}$ & $1.09 \mathrm{bB}$ \\
\hline 8 & $(\mathrm{Z})-$ & $3.75 \mathrm{aA}$ & $2.66 \mathrm{aA}$ & $1.85 \mathrm{aA}$ & $3.22 \mathrm{aA}$ \\
\hline \multirow[t]{2}{*}{9} & Octanoic acid methyl ester & $11.56 \mathrm{bB}$ & $24.20 \mathrm{aA}$ & $8.21 \mathrm{cC}$ & $13.13 \mathrm{bB}$ \\
\hline & Total & $62.95 \mathrm{bB}$ & $87.02 \mathrm{aA}$ & $89.38 \mathrm{aA}$ & $90.41 \mathrm{aA}$ \\
\hline
\end{tabular}

\section{Conclusions}

The influence of iron sulfate foliar spray on the pineapple fruit weight, external quality and internal quality were studied in this research. Results showed that folia spray of iron sulfate can enhance pineapple fruit yield to some extent with no significant difference. $0.75 \%$ treatment made the highest fruit weight, the longest longitudinal diameters, and lowest crown weight, decrease the brix value, total soluble sugars and increase total titrable acids and Vitamin C. Treatment $0.75 \%$ contained the most abundant hexanoic acid methyl ester, which means much stronger pleasant aroma, 3-(Methyltio) propanoic acid methyl ester and 2-methyl butanoic acid methyl ester. Hence, $0.75 \%$ was the best foliar spray concentration for iron sulfate on pineapple cv. Yellow Mauritius.

\section{Acknowledgments}

The research was supported by National Key R\&D Program of china (2020YFD1000600-10), the Central Public-interest Scientific Institution Basal Fund for Chinese Acedemy of Tropical Agricultural Sciences (No.1630062017025), Technical test demonstration Fund for Tropical crops of Ministry of Agriculture
(No.15162130106232002), and Guangdong Provincial Special Fund For Modern Agriculture Industry Technology Innovation Teams.

\section{References}

1. Dong-mei Liang, Xin-feng Zhao, Jian-yao, Li-kun Chen, Ji-fu Cao. Soil permeability in relation to ground water recharge from Rainfall Infiltration in the Leizhou Peninsula [J]. Tropical geology, 2016, 06: 960-968.

2. Ya-lan Liu, Wei-qi Shi, Hai-yang Ma, Jiang-zhou Zhang, Cheng-ming Yan. Influence of different $\mathrm{N}$ application levels on yield and fruit quality of pineapple [J]. Guangdong Agricultural Sciences, 2013, 40(18):49-51.

3. A.M. Arshad, A.A. Marzuki and A. Aziz. Effect of Foliar Copper Fertilizer on Pineapple cv. N36 Planted on BRIS Soil at East Coast of Peninsular Malaysia [J]. Journal of Environmental Science and Engineering, 2011(05): 1678-1682.

4. Jing Chen, Guang-ming Sun, Wei-qi Shi, Ai-min Xi, Li-qing Du. Effects of Spraying Fe and Organic Acids on Controlling Etiolation and Yields of Pineapple [J]. Chinese Journal of Tropical agriculture, 2014(06):6- 
$9+13$.

5. D.P. Bartholomew, R.E. Paull, K. G. Rohrbach. The Pineapple: Botany, Production, and Uses[M]. USA: CABI publishing, 2003.

6. AOAC (1984). Official Methods of Analysis. 14th ed. Association of Official Analytical Chemists, Washington D.C. ,985.

7. AOAC (1990). Official Methods of Analysis. 15th ed. Association of Official Analytical Chemists, Washington D.C. , 1005.

8. GB 6195-86. (1986). Determination of vitamin C In vegetables and fruits. (2, 6- dichloro-indophenolt itration method) Jiangsu, Ministry of Agricluture, China.

9. Plummer DT (1987). Introduction to Practical Biochemistry. 3rd Ed. McGraw Hill Book Company Ltd, London. 179-180.

10. Chang-bin Wei, Sheng-hui Liu, Xin-hua Lu, Qingsong $\mathrm{Wu}$, Guang-ming Sun. Analysis of aroma compounds and characteristic aroma in 6 pineapple varieties [J]. Guangdong Agricultural Sciences, 2015(24):111-116. 